\title{
Econometric Analysis of Macro Influencing Factors of Housing Prices in China - Comparison of two period data based on EVIEWS
}

\author{
Mengmeng Su', Zhifei $\mathrm{Li}^{1,2}$ \\ ${ }^{1}$ School of Business, Hubei University, Wuhan 430062, China. \\ ${ }^{2}$ Tourism Development Institute, Hubei University, Wuhan 430062, China.
}

\begin{abstract}
As one of the pillar industries of the country, the real estate industry has developed rapidly under the influence of the market economy and people's needs. The rising housing prices have brought a serious burden to the residents. The introduction of relevant regulatory policies has not significantly inhibited the high housing prices.Therefore, this paper takes the two periods of 1992-2001 and 2006-2015 as the two stages of real estate development and rapid development. The real estate price is the research object, and the relevant economic influence factors are selected from the macroscopic point of view.This paper analyzes and tests through Eviews software and establishes appropriate regression models to determine the main macro factors that affect housing prices.According to the comprehensive analysis of the results of the two-stage model, it is found that the money supply is always one of the factors of housing prices, and the influence is increasing. At the same time, the consumer price index has a great influence on the housing prices in 1992-2001. However, in 2006-2015 this factor was relatively reduced or even not.Finally, this paper proposes relevant policy recommendations for housing prices regulation through analysis results.
\end{abstract}

Keywords: Housing Prices; Macro Influencing Factors; Metrological Analysis
${ }^{*}$ Correspondence to Author:

Su Zhifei Li

Tourism Development Institute, Hubei University, Wuhan 430062 , China.

How to cite this article:

Mengmeng Su, Zhifei Li. Econometric Analysis of Macro Influencing Factors of Housing Prices in ChinaComparison of two period data based on EVIEWS. Global journal of Economics and Business Administration, 2019, 3:21

\section{eScî̀Pub}

eSciPub LLC, Houston, TX USA. Website: http://escipub.com/ 


\section{Introduction}

With the reform of China's housing system, the real estate industry has gradually appeared in the public eye. Under the dual promotion of people's needs and capital markets, the real estate industry has developed rapidly and played an irreplaceable role in the national economy. According to relevant data, the contribution rate of real estate to GDP growth increased from 16.57 $\%$ to $21.37 \%$ in $1998-2012$; the contribution rate of real estate development investment to GDP growth increased from $6.32 \%$ in 1997 to $13 \%$ in $2008{ }^{[1]}$.At the same time, the bank's credit scale to the real estate market continues to expand, which has greatly stimulated the development of the real estate market. The continuous growth of housing prices is complementary to it. From 1998 to 2015 , the average selling price of real estate rose by nearly 2.3 times ${ }^{[2] . I n ~ r e c e n t ~}$ years, in the face of rising housing prices, in order to maintain the balance between the average real estate sales price index and the consumer price index for the same period, and to prevent the occurrence of "real estate bubble", the government has successively introduced a series of "control measures to curb housing prices". From January 2010, the government issued "National Eleventh" to limit loans to the real estate market. At the same time, the central bank raised the deposit reserve ratio twice in a row. By 2011, the "National Eight Articles" stipulated that the second suite's lending should be no less than $60 \%$. Raise the deposit reserve ratio and raise interest rates by 0.25 percentage points. In July 2011, the "Upgrade Five Articles" stipulated that the first lending rate would rise by $5 \%-10 \%$, and the interest rate policy would increase the 0.25 percentage point of the oneyear deposit and loan benchmark interest rate. Although the growth trend of housing prices has eased, there are still related problems and con- tradictions. Scholars have also studied housing prices and related factors from a relevant perspective. Goodhart and Hofmann analyzed the relationship between housing prices and monetary credit in seventeen industrialized countries by establishing a panel VAR model [3]. Qing Wang and Xinyi Han used the GARCH mean equation model and the BEKK model to study the relationship between real estate prices, money supply and economic growth. The study selected the money supply, home sales price index and GDP quarterly data from the first quarter of 1998 to the first half of 2008 as research samples. The results of the study show that changes in the money supply cause changes in real estate prices, but real estate prices have no significant impact on economic fluctuations ${ }^{[4]}$. Liping Wang empirically tests the influencing factors of real estate prices through the extreme boundary analysis method. The conclusion is that the government is the main driver of high real estate prices. At the same time, the rigid demand formed by population and resident income growth is still a stable factor affecting real estate prices ${ }^{[5]}$. Yunqi Fan and Yiming Wang used dynamic panel data model and recursive analysis method to empirically analyze the regional differences in housing price influencing factors. The research shows that the income factor has no significant effect on the eastern region. The rent has a significant impact on housing prices in the western region. The land cost has influence ${ }^{[6]}$.

This paper links housing prices to related macroeconomic factors by selecting the two stages of the real estate industry (1992-2001) and rapid development (2006-2015). The EVIEWS software is used to perform quantitative analysis on the collected data and establish a mathematical model. According to the quantitative analysis of the macro-influence factors taken in the two 
Mengmeng Su et al., GJEBA, 2019; 3:21

stages, this paper compares the regression models of two decades, analyzes the main factors affecting real estate prices, and finally draws conclusions and puts forward constructive opinions.

\section{The proposal of real estate related poli- cies and the determination of macro influ- ence factors}

In the 19th National Congress, President $\mathrm{Xi}$ Jinping pointed out that we should insist on the positioning of "the house is used for living, not for speculation", and accelerate the establishment of a multi-subject supply, multi-channel guarantee, rent-and-purchase housing system to achieve the living of all people. Through the implementation of multiple policies, the government regulates speculation and curbs the "real estate bubble" with a view to safeguarding the housing problem of the people ${ }^{[7]}$. However, housing prices have always been one of the focuses of people's lives and one of the main factors affecting people's living standards ${ }^{[8]}$. The analysis of the macro-influence factors of real estate prices and the understanding of government policies are closely related to the people's living needs, which is also the significance of this paper. At the same time, the paper selects two ten-year intervals as the time range is mainly affected by the following related policies: First, In 1992, China comprehensively promoted market economic reforms, and major changes have taken place in related industries and fields. The active market economy has had a huge impact on the real estate market and laid the foundation for the start and rapid development of the real estate market. At the same time, Since the statistical data has a certain change after 1992, there will be some deviations in the comparative analysis. Therefore, this paper selects 1992 as the starting point of the sample one data. The $t-$ ime range for collecting macroeconomic indicat- ors in sample one ranged from 1992 to 2001.

Second, The definition of the interest rate of the loan is generally classified by the interest rate category within a five-year period. In 1998, China introduced a currency allocation policy to replace the physical housing policy ${ }^{[9]}$, and longterm loan interest rates became an important consideration in housing transactions. Referring to the selection time of sample one, the country's interest rate adjustment in 2005 is relatively frequent, so that a reasonable interest rate value cannot be determined, and the long-term loan interest rate (more than 5 years) is used as the base. Therefore, this paper selects 2006 as the starting point of the sample two data. The time range for collecting macroeconomic indicators in sample two ranged from 2006 to 2015. According to the introduction of the above relevant macro policies, this paper selects relevant economic indicators for research. The average selling price of housing is the explanatory variable, and the measurement is analyzed from the following four main influencing factors: (1)Per capita disposable income of urban households (INC). The variable reflects the part of the household's total cash income that can be used to arrange the daily life of the family. It is the income of the family's total income minus the paid income, the social security fees paid by the individual, and the income of the survey households. The per capita disposable income of urban residents directly reflects the living standards of urban residents and is one of the important factors for social stability. It also marks the purchasing power of residents and can be used to measure the income level and living standards of urban residents ${ }^{[10]}$. With the economic growth, the disposable income of urban residents has increased significantly, which has greatly improved the actual purchasing power of urban residents ${ }^{[11]}$. (2) Money supply 
(M2). According to the three levels of China's current money supply, the impact of various levels of money supply on housing prices is examined. At the same time, the different effects of their impact on housing prices are compared horizontally. M2, M1 and M0 are always positive for real estate prices. M2 (generalized) has a greater impact on real estate prices than $\mathrm{M} 1$ and $M 0^{[7]}$. This paper selects $M 2$ as the research variable. The variable refers to the total amount of money held by the relevant departments such as individuals and enterprises in a country's economy, including the deposit currency and cash currency supplied by financial institutions including the central bank. The money supply steadily reflects the economic development of various countries and provides an important basis for the central bank to stabilize the currency [12]. (3)Consumer Price Index (CPI) . This variable is a relative number reflecting the changes in household consumption levels, and is also one of the important indicators reflecting a country's macroeconomic performance. It is also the main indicator for the central bank to determine interest changes ${ }^{[13]}$.Accurately making predictions of the Consumer Price Index (CPI) can provide an important basis for the relevant national or regional authorities to develop reasonable development plans and optimize the allocation of resources[14]. (4) Long-term loan inter- est rate (more than 5 years) ( $R$ ). The loan interest rate is divided into a one-year bank loan benchmark interest rate, one to three years, three to five years, and a five-year bank lending benchmark interest rate, and they are constantly being adjusted ${ }^{[15]}$. This variable is mainly used as a variable that affects real estate supply and demand. In theory, rising interest rates will lower real estate prices ${ }^{[11]}$.China's long-term implementation of interest rate control, the benchmark loan interest rate is significantly lower than the market interest rate, thereby reducing the cost of capital, stimulating the investment behavior of the whole society, resulting in high investment rate ${ }^{[16]}$.

\section{Data collection and regression analysis of influencing factors}

\subsection{Data collection}

This paper selects the relevant data of each variable in 1992-2001 and 2006-2015 by referring to the relevant data of the National Bureau of Statistics of the People's Republic of China, China Economic Net and China Statistical Yearbook, as shown in Tables 1 and Tables2.Among them: $Y$ is the average selling price of commodity houses (yuan/square meter); $\mathrm{X} 1$ is the per capita disposable income of urban households (yuan); $\mathrm{X} 2$ is the money supply (100 million yuan); $X 3$ is the consumer price index $(1978=100) ; X 4$ is the long-term loan interest rate (more than five years).

Table 1 Data of average housing sales price and household consumption index from 1992 to 2001

\begin{tabular}{|c|c|c|c|c|c|c|c|c|c|c|}
\hline years & 2001 & 2000 & 1999 & 1998 & 1997 & 1996 & 1995 & 1994 & 1993 & 1992 \\
\hline $\mathrm{Y}$ & 2170 & 2112 & 2053 & 2063 & 1997 & 1806 & 1591 & 1409 & 1291 & 995 \\
\hline $\mathrm{X} 1$ & 6859.6 & 6280.0 & 5854.0 & 5425.1 & 5160.3 & 4838.9 & 4283.0 & 3496.2 & 2577.4 & 2026.6 \\
\hline $\mathrm{X} 2$ & 158310.9 & 134610.4 & 119897.9 & 104498.5 & 90995.3 & 76094.9 & 60750.5 & 46923.5 & 34879.8 & 25402.2 \\
\hline $\mathrm{X} 3$ & 479.9 & 476.6 & 472.8 & 479.0 & 481.9 & 467.4 & 429.6 & 367.8 & 294.2 & 253.4 \\
\hline $\mathrm{X} 4$ & 6.21 & 6.21 & 6.89 & 9.23 & 12.11 & 13.51 & 13.86 & 13.86 & 11.76 & 9.54 \\
\hline
\end{tabular}

Table 2 Data of average housing sales price and household consumption index from 2006 to 2015

\begin{tabular}{|l|l|l|l|l|l|l|l|l|l|l|}
\hline years & 2015 & 2014 & 2013 & 2012 & 2011 & 2010 & 2009 & 2008 & 2007 & 2006 \\
\hline
\end{tabular}


Mengmeng Su et al., GJEBA, 2019; 3:21

\begin{tabular}{|c|c|c|c|c|c|c|c|c|c|c|}
\hline $\mathrm{Y}$ & 6793.00 & 6324.00 & 6237.00 & 5790.99 & 5357.10 & 5032.00 & 4681.00 & 3800.00 & 3863.90 & 3167.66 \\
\hline $\mathrm{X} 1$ & 31195 & 28844 & 26955 & 24565 & 21810 & 19109 & 17175 & 15781 & 13786 & 11760 \\
\hline $\mathrm{X} 2$ & 400953 & 348056 & 337291 & 308664 & 289848 & 266622 & 221446 & 166217 & 152560 & 126028 \\
\hline $\mathrm{X} 3$ & 615.2 & 606.7 & 594.8 & 579.7 & 565.0 & 536.1 & 519.0 & 533.7 & 493.6 & 471.0 \\
\hline $\mathrm{X} 4$ & 4.90 & 6.15 & 6.55 & 6.55 & 7.05 & 6.40 & 5.94 & 5.94 & 11.76 & 9.54 \\
\hline
\end{tabular}

Note: The data comes from the National Bureau of Statistics of the People's Republic of China, China Economic Net, China Statistical Yearbook.

\subsection{Regression analysis}

This section uses EVIEWS to make a scatter plot of the interpreted variable $(Y)$ and the expl- anatory variables $(\mathrm{X} 1, \mathrm{X} 2, \mathrm{X} 3, \mathrm{X} 4)$ (Figure 1 shows the scatter plot for 1999-2001, Figure 2 shows 2006-2015).

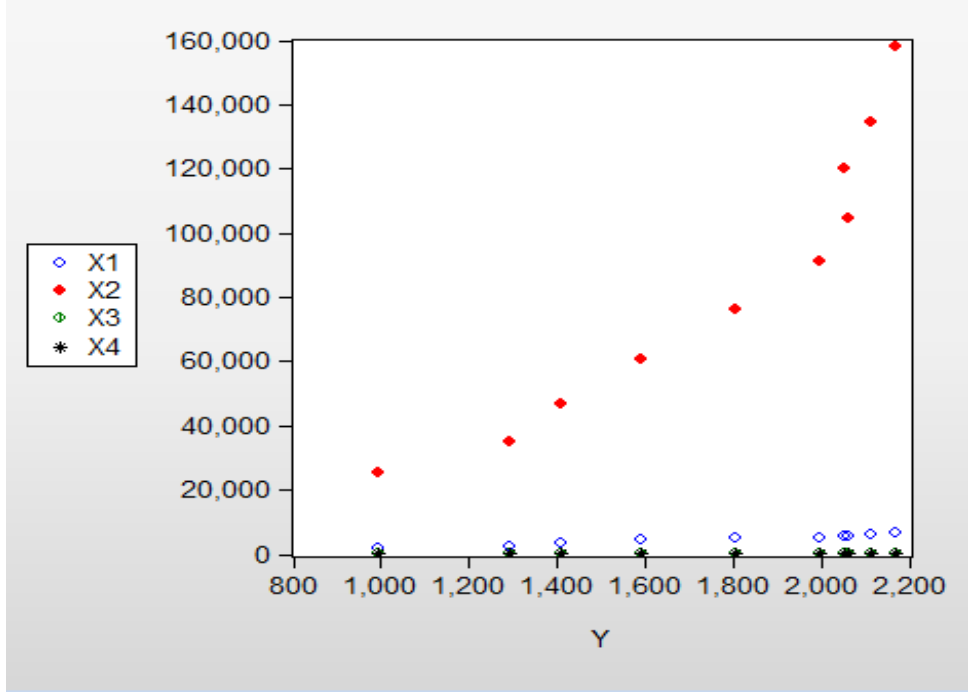

Figure 1 Scatter plot of $x 1 \times 2 \times 3 \times 4$ and y (1992-2001)

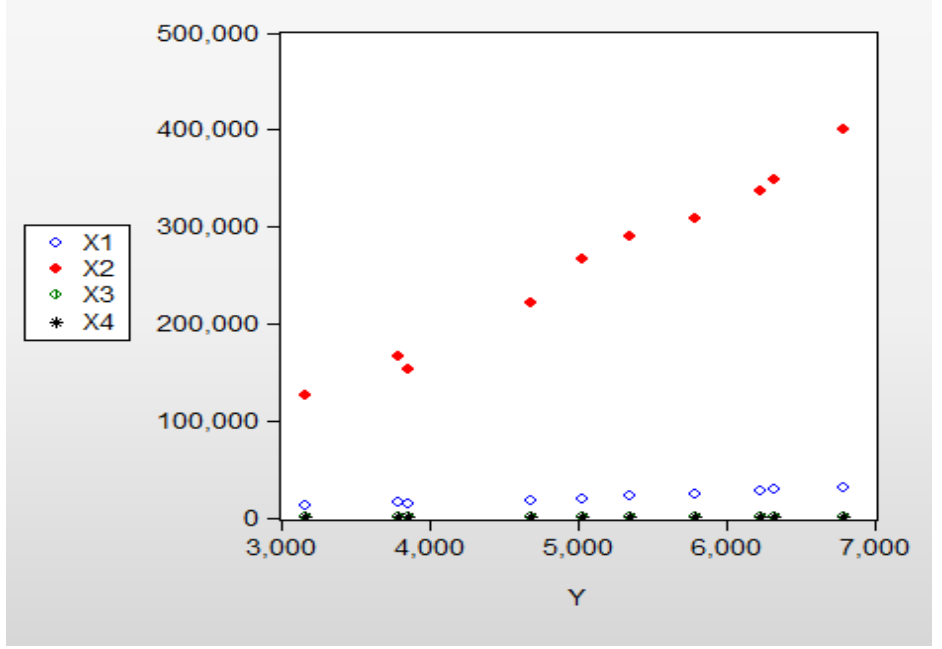

Figure 2 Scatter plot of $x 1 \times 2 \times 3 \times 4$ and y (2006-2015)

It can be seen from the scatter plot 1 and the scatter plot 2 that the factor $\mathrm{X} 2$ increases with the increase in the average selling price $Y$ of the commercial housing, whether it is 1992-2001 or
2006-2015, and Figure 1 tends to rise straight in the later period. The factors $\mathrm{X} 1, \mathrm{X} 3$, and $\mathrm{X} 4$ are approximately linear with the dependent varia- 
ble $\mathrm{Y}$, and the two graphs have similar characteristics. Based on the basis of scatter plots, this paper considers the establishment of multiple linear regression equations. It is assumed that the model and its random perturbation term ui satisfy the classical assumptions. The OLS method is used to estimate the parameters, and the EVIEWS software is used to estimate the model parameters [17]. The regression results are shown in Table 3 (1992-2001) and Table 4 (2006-2015).

Table 3 Results of a multiple linear regression (1992-2001)

\begin{tabular}{|c|c|c|c|c|}
\hline \multicolumn{5}{|c|}{ Depengdengt Variable: Y } \\
\hline \multicolumn{5}{|c|}{ Method: Least Squares } \\
\hline \multicolumn{5}{|c|}{ Date: 09/22/19 } \\
\hline \multicolumn{5}{|c|}{ Sample: 19922001} \\
\hline \multicolumn{5}{|c|}{ Include observations: 10} \\
\hline Variable & Coefficient & Std.Error & t-Statistic & Prob. \\
\hline C & -4.422585 & 194.8149 & -0.022701 & 0.9828 \\
\hline $\mathrm{X} 1$ & -0.611749 & 0.287385 & -2.128678 & 0.0865 \\
\hline$x 2$ & 0.019359 & 0.008194 & 2.362525 & 0.0645 \\
\hline X3 & 6.856439 & 1.809390 & 3.789365 & 0.0128 \\
\hline $\mathrm{X} 4$ & 8.201255 & 19.99408 & 0.410184 & 0.6987 \\
\hline R-squared & 0.989778 & \multicolumn{2}{|c|}{ Mean dependent var } & 1748.700 \\
\hline Adjusted R-squared & 0.981600 & \multicolumn{2}{|c|}{ S.D.dependent var } & 406.0129 \\
\hline S.E.of regression & 55.073700 & \multicolumn{2}{|c|}{ Akaike info criterion } & 11.16207 \\
\hline Sum squared resid & 15165.56 & \multicolumn{2}{|c|}{ Schwarz criterion } & 11.31337 \\
\hline Log likelihood & -50.81037 & \multicolumn{2}{|c|}{ Hannan-Quinn criter } & 10.99611 \\
\hline F-statistic & 121.0351 & \multicolumn{2}{|c|}{ Durbin-Watson stat } & 2.292924 \\
\hline Prob(F-statistic) & 0.000037 & & & \\
\hline
\end{tabular}

From the data in Table 3, the results of the 1992-2001 estimation equation are: $Y=-4.4226-0.6117 X 1+0.0194 X 2+6.8564 X 3+8.2013 X 4$

$R^{\wedge} 2=0.9899$, adjusted $R^{\wedge} 2=0.9816, F=121.0351, n=10$

Table 4 Results of a multiple linear regression (2006-2015)

\begin{tabular}{|c|c|c|c|c|}
\hline \multicolumn{5}{|c|}{ Depengdengt Variable: $Y$} \\
\hline \multicolumn{5}{|c|}{ Date: 09/22/19 Time: 19:52 } \\
\hline \multicolumn{5}{|c|}{ Sample: 2006 2015 } \\
\hline Include observations: 10 \\
\hline Variable & Coefficient & Std.Error & t-Statistic & Prob. \\
\hline C & 987.0866 & 2166.171 & 0.455683 & 0.6677 \\
\hline X1 & 0.047323 & 0.059697 & 0.792716 & 0.4639 \\
\hline X2 & 0.010367 & 0.002890 & 3.586791 & 0.0158 \\
\hline
\end{tabular}

GJEBA: https://escipub.com/global-journal-of-economics-and-business-administration/ 
Mengmeng Su et al., GJEBA, 2019; 3:21

\begin{tabular}{|c|c|c|c|c|}
\hline X3 & -0.354377 & 5.213463 & -0.067974 & 0.9484 \\
\hline X4 & 93.66511 & 74.75531 & 1.252956 & 0.2656 \\
\hline R-squared & 0.992046 & \multicolumn{2}{|c|}{ Mean dependent var } & 5104.665 \\
\hline Adjusted R-squared & 0.985682 & S.D.dependent var & 1217.128 \\
\hline S.E.of regression & 145.637100 & Akaike info criterion & 13.10679 \\
\hline Sum squared resid & 106050.8 & Schwarz criterion & 13.25826 \\
\hline Log likelihood & -60.53483 & Hannan-Quinn criter & 12.94100 \\
\hline F-statistic & 155.898900 & Durbin-Watson stat & 2.196973 \\
\hline Prob(F-statistic) & 0.000020 & \multicolumn{2}{|}{} \\
\hline
\end{tabular}

From the data in Table 3, the results of the 1992-2001 estimation equation are:

$Y=987.0866-0.0473 X 1+0.0103 X 2-0.3543 \times 3+93.6651 X 4$

$R^{\wedge} 2=0.9920$, adjust $R^{\wedge} 2=0.9857, F=155.8989, n=10$

\section{Test and adjustment of solution results}

\subsection{Economic significance test}

According to economic analysis, from 1992 to 2001, the sales price of commercial housing $(Y)$ and urban households disposable income (X1), money supply (X2), consumer price index (X3), long-term loan interest rate (more than five years) (x4) should be positively correlated. However, in the multiple regression model, the coefficient of the coefficient of urban household per capita disposable income (X1) is negative, indicating that this variable is negatively correlated. This is inconsistent with the meaning of economics, so it is considered that the original model is wrong and needs to be adjusted.

During 2006-2015, commercial housing sales price $(\mathrm{Y})$ and urban household per capita disposable income (X1), money supply (X2), consumer price index $(X 3)$, long-term loan interest rate (more than five years) (X4) should be positively correlated. However, the coefficient symbol before the consumer price index (X3) in the multiple regression model is negative, indicating that this variable is negatively correlated. This is inconsistent with the meaning of economics, so it is considered that the original model is wrong and needs to be adjusted.

\subsection{Statistical test}

It can be seen from the above regression results that the values of the determinable coefficient $\mathrm{R}^{\wedge} 2$ and the modified determinable coefficient $\mathrm{R}^{\wedge} 2$ of Tables 3 and 4 are both close to 1 , indicating that the goodness of fit of the model is high. At the significance level of $\alpha=0.05$, the $t$ statistic value of $X 3$ in Table 3 passed the significance test. However, the $P$ value of $X 2$ is 0.0645 , and the $P$ value of $X 4$ is 0.6987 , both of which are greater than 0.05 , so the result is not significant. In Table 4, the $\mathrm{t}$ statistic value of $\mathrm{X} 2$ passed the significance test. Since the $P$ value of $X 1$ is 0.4639 and the $P$ value of $X 4$ is 0.2659 , which is greater than 0.05 , the result is not significant. The above indicates that there are errors in the two models established and we need to make adjustments.

\subsection{Econometric test}

(1) The correlation coefficients of X1, X2, X3 and X4 from 1992 to 2001 are shown in Table 5. It can be seen from Table 5 that the correlation coefficients of the relevant variables are relatively high, and there is a serious multicollinearity problem. Therefore, We use stepwise regression to eliminate some variables ${ }^{[18]}$. It can be seen from the regression results of all variables that the significance level of $\mathrm{X} 4$ test is very low, and its $P$ value is much larger than 0.05 . First, 
this factor is removed from the model, and then such as Table 6 shows. removed and then returned [17], we get results

Table 5 Correlation coefficient matrix

\begin{tabular}{|c|c|c|c|c|c|}
\hline \multicolumn{5}{|c|}{ Correlation } \\
\hline & $\mathrm{Y}$ & $\mathrm{X} 1$ & $\mathrm{X} 2$ & $\mathrm{X} 3$ & $\mathrm{X} 4$ \\
\hline $\mathrm{Y}$ & 1.000000 & 0.976821 & 0.934703 & 0.955231 & -0.509385 \\
\hline $\mathrm{X} 1$ & 0.976821 & 1.000000 & 0.974437 & 0.929214 & -0.574620 \\
\hline $\mathrm{X} 2$ & 0.934703 & 0.974437 & 1.000000 & 0.827095 & -0.730862 \\
\hline $\mathrm{X} 3$ & 0.955231 & 0.929214 & 0.827095 & 1.000000 & -0.276804 \\
\hline $\mathrm{X} 4$ & -0.509385 & -0.574620 & -0.730862 & -0.276804 & 1.000000 \\
\hline
\end{tabular}

Table 6 Modified regression results

\begin{tabular}{|c|c|c|c|c|}
\hline \multicolumn{5}{|c|}{ Depengdengt Variable: Y } \\
\hline \multicolumn{5}{|c|}{ Dethod: Least Squares $09 / 22 / 19$ Time: 22:00 } \\
\hline \multicolumn{5}{|c|}{ Sample: 1992 2001 } \\
\hline Include observations: 10 \\
\hline Variable & Coefficient & Std.Error & t-Statistic & Prob. \\
\hline C & 238.0364 & 141.2851 & 1.684794 & 0.1359 \\
\hline X2 & 0.004198 & 0.000900 & 4.663389 & 0.0023 \\
\hline X3 & 2.743231 & 0.467119 & 5.872657 & 0.0006 \\
\hline R-squared & 0.978685 & Mean dependent var & 1748.700 \\
\hline Adjusted R-squared & 0.972595 & S.D.dependent var & 406.0129 \\
\hline S.E.of regression & 67.212940 & Akaike info criterion & 11.49693 \\
\hline Sum squared resid & 31623.06 & Schwarz criterion & 11.58771 \\
\hline Log likelihood & -54.48467 & Hannan-Quinn criter & 11.39735 \\
\hline F-statistic & 160.705 & Durbin-Watson stat & 1.814588 \\
\hline Prob(F-statistic) & 0.000001 & \multicolumn{5}{c}{} \\
\hline
\end{tabular}

From the regression results corrected in Table 6, it can be seen that after eliminating the factors $\mathrm{X} 1$ and $\mathrm{X} 4, \mathrm{R}^{\wedge} 2$ is 0.9787 , and the adjusted $\mathrm{R}^{\wedge} 2$ is 0.9726 , which indicates that the fitting effect is good.. $F$ is 160.7050 , which is much larger than the critical value and passed the $F$ test. At the same time, the $P$ values of $X 2$ and $X 3$ are less than 0.05, and the statistical test is also passed. So we come to the multiple regression model as follows:
$Y=238.0364+0.0042 X 2+2.7432 X 3$

(2)The correlation coefficients of X1, X2, X3 and X4 from 2006 to 2015 are shown in Table 7. It can be seen from Table 7 that the correlation coefficients of the relevant variables are relatively high, and there is a serious multicollinearity problem. Therefore, We use stepwise regression to eliminate some variables ${ }^{[5,6]}$. It can be seen from the regression results of all variables that the significance level of $\mathrm{X} 4$ test is very low, 
and its $P$ value is much larger than 0.05 . First, removed and then returned ${ }^{[7]}$, we get results this factor is removed from the model, and then such as Table 8 shows

Table 7 Correlation coefficient matrix

\begin{tabular}{|c|c|c|c|c|c|}
\hline \multicolumn{5}{|c|}{ Correlation } \\
\hline & $Y$ & $X 1$ & $X 2$ & $X 3$ & $X 4$ \\
\hline$Y$ & 1.000000 & 0.983894 & 0.994033 & 0.959516 & -0.496947 \\
\hline$X 1$ & 0.983894 & 1.000000 & 0.982754 & 0.980998 & -0.549453 \\
\hline$X 2$ & 0.994033 & 0.982754 & 1.000000 & 0.957759 & -0.537626 \\
\hline$X 3$ & 0.959516 & 0.980998 & 0.957759 & 1.000000 & -0.542018 \\
\hline$X 4$ & -0.496947 & -0.549453 & -0.537626 & -0.542018 & 1.000000 \\
\hline
\end{tabular}

Table 8 Modified regression results

\begin{tabular}{|c|c|c|c|c|}
\hline \multicolumn{5}{|c|}{ Depengdengt Variable: $Y$} \\
\hline \multicolumn{5}{|c|}{ Method: Least Squares } \\
\hline \multicolumn{5}{|c|}{ Date: 09/22/19 } \\
\hline \multicolumn{5}{|c|}{ Sample: 20062015} \\
\hline \multicolumn{5}{|c|}{ Include observations: 10} \\
\hline Variable & Coefficient & Std.Error & t-Statistic & Prob. \\
\hline C & 1672.675 & 140.4019 & 11.91348 & 0.0000 \\
\hline $\mathrm{X} 2$ & 0.013111 & 0.000509 & 25.77481 & 0.0000 \\
\hline R-squared & 0.988101 & \multicolumn{2}{|c|}{ Mean dependent var } & 5104.665 \\
\hline Adjusted R-squared & 0.986614 & \multicolumn{2}{|c|}{ S.D.dependent var } & 1217.128 \\
\hline S.E.of regression & 140.819500 & \multicolumn{2}{|c|}{ Akaike info criterion } & 12.90969 \\
\hline Sum squared resid & 158641.1 & \multicolumn{2}{|c|}{ Schwarz criterion } & 12.97021 \\
\hline Log likelihood & -62.54846 & \multicolumn{2}{|c|}{ Hannan-Quinn criter } & 12.84330 \\
\hline F-statistic & 664.3409 & \multicolumn{2}{|c|}{ Durbin-Watson stat } & 2.25064 \\
\hline Prob(F-statistic) & 0.000000 & & & \\
\hline
\end{tabular}

From the regression results corrected in Table 8 ,it can be seen that after eliminating the factors $\mathrm{X} 1, \mathrm{X} 3$ and $\mathrm{X} 4, \mathrm{R}^{\wedge} 2$ is 0.9881 , and the adjusted $\mathrm{R}^{\wedge} 2$ is 0.9866 , which indicates that the fitting effect is good. $F$ is 664.3409, which is much larger than the critical value and passed the $F$ test. At the same time, the $P$ values of $X 2$ is less than 0.05 , and the statistical test is also passed. So we come to the multiple regression model as follows: $Y=1672.675+0.0131 \mathrm{X} 2$

\subsection{Auto-correlation test}

\subsubsection{DW test method}

In 1992-2001, the sample size is 10 , the model of two explanatory variables, and the significant level of $5 \%$. The DW table shows that when the sample size is $15, \mathrm{dL}=0.95, \mathrm{dU}=1.54$. However, $\mathrm{DW}=1.8146>\mathrm{dL}$ in the model, so there is no auto-correlation problem in the established model.

In 2006-2015, the sample size is 10 , a model for explanatory variables, and a significant level of $5 \%$. At the same time, it is known that $\mathrm{dL}=1.08$ 
and $\mathrm{dU}=1.36$. In the model, $\mathrm{DW}=2.2506>\mathrm{dL}$, so the established model does not have auto-correlation problems.

\subsubsection{Breusch-Godfrey test (LM test)}

In the output of the EVIEWS regression, we click on "View/Residual Diagnostics/Serial Correlation LM Test" and select the lag order "2" in "lags to include" to get the BG test result.As shown in Table 9 (1992-2001) and Table 10 (2006-2015):

Table 9 BG test results (1992-2001)

\begin{tabular}{|c|c|c|c|}
\hline \multicolumn{4}{|c|}{ Breusch-Godfrey Serial Correlation LM Test: } \\
\hline F-statistic & 0.522096 & Prob.F(2,5) & 0.6224 \\
\hline Obs*R-squared & 1.727596 & Prob.Chi-Square(2) & 0.4216 \\
\hline
\end{tabular}

From the results of Table 9, it can be seen that $n R^{\wedge} 2=1.7276<x^{\wedge} 20.05=5.9915$, and the probability value $P$ is much larger than 0.05 , indica- ting that there is no auto-correlation. We don't need to make adjustments to the model.

Table 10 BG test results (2006-2015)

\begin{tabular}{|c|c|c|c|}
\hline \multicolumn{4}{|c|}{ Breusch-Godfrey Serial Correlation LM Test: } \\
\hline F-statistic & 0.450723 & Prob.F(2,3) & 0.6743 \\
\hline Obs*R-squared & 2.310542 & Prob.Chi-Square(2) & 0.3150 \\
\hline
\end{tabular}

From the results of Table 10, it is known that $n R^{\wedge} 2=2.3105<x^{\wedge} 20.05=5.9915$, and the probability value $P$ is much larger than 0.05 , indicating that there is no auto-correlation. We don't need to make adjustments to the model.

\subsubsection{Partial correlation coefficient test}

In this paper, the EVIEWS software is used to calculate the partial correlation coefficient. We click on View/Residual Test/Correlogram-Q-statistics in the equation window, and input the lag period to 10 , which can get the phase relationship and result of each phase (Figure 3 19922001)) (Figure 4 2006-2015).

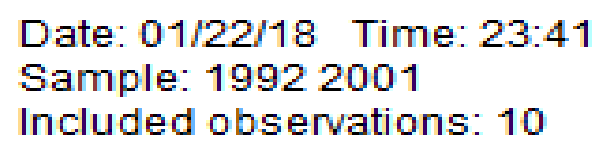

\begin{tabular}{|c|c|c|c|c|c|c|c|c|c|c|}
\hline \multicolumn{3}{|c|}{ Autocorrelation } & \multicolumn{3}{|c|}{ Partial Correlation } & \multicolumn{2}{|r|}{$\mathrm{AC}$} & \multirow{2}{*}{$\begin{array}{l}\text { PAC } \\
0.023\end{array}$} & \multirow{2}{*}{$\frac{\text { Q-Stat }}{0.0070}$} & \multirow{2}{*}{$\begin{array}{c}\text { Prob } \\
0.933\end{array}$} \\
\hline 1 & & 1 & $\mathbf{I}$ & & 1 & 1 & 0.023 & & & \\
\hline 1 & $\square$ & 1 & 1 & & 1 & 2 & -0.378 & -0.378 & 2.1451 & 0.342 \\
\hline 1 & ᄃ & 1 & 1 & & 1 & 3 & -0.362 & -0.398 & 4.3896 & 0.222 \\
\hline 1 & & 1 & 1 & 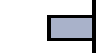 & 1 & 4 & 0.017 & -0.216 & 4.3951 & 0.355 \\
\hline 1 & $\sqsupseteq$ & 1 & $\mathbf{I}$ & 망 & 1 & 5 & 0.182 & -0.191 & 5.1872 & 0.393 \\
\hline 1 & 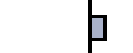 & 1 & 1 & 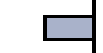 & 1 & 6 & 0.067 & -0.235 & 5.3215 & 0.503 \\
\hline 1 & & 1 & 1 & & 1 & 7 & 0.038 & -0.081 & 5.3795 & 0.614 \\
\hline 1 & 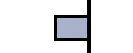 & 1 & 1 & ᄂ & 1 & 8 & -0.156 & -0.290 & 6.8457 & 0.553 \\
\hline 1 & $p$ & 1 & $\mathbf{I}$ & & 1 & 9 & 0.069 & -0.023 & 7.4244 & 0.593 \\
\hline
\end{tabular}

Figure 3 Partial correlation coefficient (1992-2001) 
Date: 01/22/18 Time: 23:40

Sample: 20062015

Included observations: 10

\begin{tabular}{|c|c|c|c|c|c|c|c|c|c|c|}
\hline \multicolumn{3}{|c|}{ Autocorrelation } & \multicolumn{3}{|c|}{ Partial Correlation } & \multicolumn{2}{|r|}{$\mathrm{AC}$} & PAC & Q-Stat & Prob \\
\hline 1 & $\square$ & 1 & I & $\square$ & I & 1 & -0.235 & -0.235 & 0.7382 & 0.390 \\
\hline I & 맘 & I & I & 口 & 1 & 2 & -0.190 & -0.259 & 1.2780 & 0.528 \\
\hline 1 & & 1 & 1 & & 1 & 3 & -0.291 & -0.464 & 2.7343 & 0.434 \\
\hline 1 & & $\mathrm{I}$ & I & 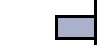 & 1 & 4 & 0.171 & -0.195 & 3.3176 & 0.506 \\
\hline I & & I & I & & 1 & 5 & 0.223 & 0.033 & 4.5104 & 0.478 \\
\hline 1 & 드 & 1 & 1 & 무 & 1 & 6 & -0.127 & -0.177 & 4.9917 & 0.545 \\
\hline 1 & 다 & $\mathrm{I}$ & I & С & 1 & 7 & -0.093 & -0.106 & 5.3358 & 0.619 \\
\hline 1 & 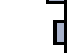 & I & I & 믄 & 1 & 8 & -0.058 & -0.105 & 5.5369 & 0.699 \\
\hline 1 & t & 1 & I & 므 & 1 & 9 & 0.100 & -0.142 & 6.7379 & 0.664 \\
\hline
\end{tabular}

Figure 4 Partial correlation coefficient (2006-2015)

It can be seen from the partial correlation coefficient graph that the straight squares of the correlation coefficients do not exceed the dotted line portion. So there is no auto-correlation, we don't need to adjust the model.

\subsection{Heteroscedasticity test (white test)}

In this section, we use the white test method to test the heteroscedasticity of the regression model. We click on View/ResiduallTestlWhite Het-eroskedastcity(no cross terms or cross ter$\mathrm{ms}$ ) on the equation window to enter the heteroscedasticity test. As shown in Table 11 and Table 12 .

Table 11 white test results (1992-2001)

\begin{tabular}{|c|c|c|c|}
\hline \multicolumn{4}{|c|}{ Heteroskedasticity Test:White } \\
\hline F-statistic & 0.246682 & Prob.F(5,4) & 0.9215 \\
\hline Obs $^{\star}$ R-squared & 2.356800 & Prob.Chi-Square(5) & 0.7979 \\
\hline Scaled expiained SS & 0.514907 & Prob.Chi-Square(5) & 0.9916 \\
\hline
\end{tabular}

As can be seen from the results in Table 11, the $P$ value for linear regression was 0.9215 , indisignificance level of 0.05 . We don't need to deal with it. cating that there was no heteroscedasticity at a

Table 12 white test results (2006-2015)

\begin{tabular}{|c|c|c|c|}
\hline \multicolumn{4}{|c|}{ Heteroskedasticity Test:White } \\
\hline F-statistic & 1.113131 & Prob.F(2,7) & 0.3804 \\
\hline Obs*R-squared & 2.412962 & Prob.Chi-Square(2) & 0.2992 \\
\hline Scaled expiained SS & 0.283244 & Prob.Chi-Square(2) & 0.8679 \\
\hline
\end{tabular}

As can be seen from the results in Table 12, the $P$ value for linear regression was 0.3805 , indicating that there was no heteroscedasticity at a significance level of 0.05 .We don't need to deal with it.

\section{Eviews analysis}

This paper first builds an equation model. Then, in order to correct the equation model, econom- 
ic significance test, statistical test and econometric test are respectively carried out. Finally, the auto-correlation test and heteroscedasticity test are carried out on the modified model to obtain the final equation model:

(1) $1992-2001$

\section{$Y=238.0364+0.0042 X 2+2.7432 \times 3$}

The equation model in sample 1 shows that when the money supply increases by 100 million yuan, the average selling price of housing will increase by 0.0042 yuan / square meter; when the household consumption index increases by one unit, the average selling price of housing increases by 2.7432 Yuan / square meter.

(2) 2006-2015

$Y=1672.675+0.0131 \times 2$

The equation model in sample 2 shows that when the money supply increases by 100 million yuan, the average selling price of commercial housing will rise by 0.0131 yuan / square meter.

\section{Comparative analysis and recommenda- tions for the two periods}

\subsection{Comparative analysis}

(1) Through the process of establishing the equation model of the data of sample 1 and sample 2, we can find that in the process of constructing the scatter plot, analysis, test and regression model of the influencing factors in the two periods, the data is different, but EVIEWS presents similar results.

(2) From the equation model established by Sample 1 (1992-2001), the macro factors that ultimately affect real estate prices are the money supply and the household consumption index. The equation model established in sample 2 (2006-2015) shows that the macro-influence factor affecting real estate prices is the money supply. Combining the equation models of the two samples shows that money supply is always the main factor affecting real estate prices.

(3)Through the comparison of the equation models of the two periods, when the money supply increases by the same unit, housing price in sample 2 increases by 0.0089 yuan per square meter, which indicates that the impact of the money supply on the real estate price is increasing. In addition, the impact index of the household consumption index on housing prices in sample 1 is very large, and the impact of the household consumption index in sample 2 does not play a role. From a certain degree of reaction, the improvement of the overall living consumption level of the nation and the change of the consumption outlook of residents have a subtle influence on housing prices.

\subsection{Recommendation}

This paper analyzes the macro factors affecting housing prices in 1992-2001 and 2006-2015 through EVIEWS tools. Through comprehensive comparative analysis of the two periods, it is found that the money supply is always an important factor affecting the real estate price, and the two have a certain correlation. With the continuous development of China's economic level and the continuous improvement of urbanization rate, the possibility that the volatility of housing prices will continue to rise in the future is still very large. Therefore, the introduction of housing price regulation and control policies is extremely urgent for the development of the entire real estate industry and related industries. As a result, how to regulate housing prices through money supply and reduce the volatility of real estate prices is a major issue that we must face. Based on the research results, this paper proposes the following policy recommendations: First, Macroeconomic regulation of money supply to regulate housing prices. The increase in the money supply promotes people's investme- 
nt in the real estate market, which affects the fluctuation of housing prices. The money supply should be strictly controlled. Second, Enrich and improve multi-channel and multi-class capital markets. In the absence of other good investment markets, funds will continue to flood into the real estate market, which will have a greater impact on housing prices. By enriching the types of capital market investments and improving the capital market system, the monetary structure will be dispersed in various capital markets, which will reduce the impact on real estate prices. Third, Other policy adjustments are coordinated. For example, housing credit policies, curbing speculative demand, etc. Through the establishment of a multi-faceted and multi-angle real estate market regulation system for monetary policy, fiscal policy and administrative regulations, the real estate market will be guaranteed to operate fairly and fairly.

Inadequacies of this paper, In this paper, only two sample data are selected and the two samples are small, and the model is not representative enough. In addition, only four influencing factors of macroeconomic regulation and control have been considered in the model establishment process, and many influencing factors have not been considered (such as population, urbanization rate, industry share, housing purchase price, completed housing area, etc.), which makes The reliability and robustness of the model are reduced. Of course, in order to effectively regulate housing prices, we still need to do a lot of work. To further consider the impact of other economic factors on real estate prices, we should proceed from the reality, achieve the goal of big data to control, and establish relevant feasibility policies.

\section{References}

1. Dongmei Wang,Zhaoliang Sun. Research on the Relationship between Social Responsibility and
Enterprise Value in Real Estate Industry_-An Empirical Analysis Based on Panel Data of Listed Companies[J].Economy and management.2011, 25(9):17-21.

2. Lingmiao Liu,Jianhua Liu,Hongfang Qiao. Regional Differences in Influencing Factors of Real Estate Price in China_-Based on Spatial Econometric Analysis[J]. Journal of Minnan Normal University (Philosophy and Social Sciences), 2018, 32(04): 72-79.

3. Goodhart, C. and Hofmann, B. House prices, Money, Credit and the Macro-economy [J], Oxford Review of Economic Policy, 2008,24(1):180 $-205$.

4. Qing Wang, Xinwei Han. Can monetary policy focus on housing prices? Evidence from the Chinese real estate market [J]. Financial Research, 2009, (8): $114 \sim 123$.

5. Liping Wang.An Empirical Study on the Factors Affecting the "Steadyness"of Real Estate Price in China[J].Management World,2013(10).

6. Yunqi Fan, Yiming Wang. Regional Differences and Time Series Changes of China's Housing Price Factors[J]. Journal of Guizhou University of Finance and Economics, 2014(1): 62.

7. Chujiang Wen.Research on the impact of money supply on China's real estate price[D].Guang zhou:Guangdong University of Foreign Studies,2013.

8. Jianhui Liu. Analysis of real estate status in Qingdao and forecast of future trends [D]. Hohai University, 2006.

9. Yuqi Cao.Econometric analysis of factors affecting real estate prices [J].Finance,2011,02:83-88.

10. Meizhen Shi. Prediction of per capita disposable income of urban residents in Shaanxi Province[J]. Tax, 2018, v.12; No.202(22):219.

11. Fen Xiong.Econometric analysis of factors affecting real estate prices in China [J].Contemporary Economy,2015,391(31):142-143.

12. Yuqiang Gao, Haoqin Qin. Social Financing Sc- 
ale and Money Supply: Analysis of the Effective-

ness of Intermediary Targets of Monetary Pol-

icy_-Based on the Test of Causality in Rolling

Boots[J]. Chongqing Social Sciences, 2019(8):

51-63.

13. Jian Wang,Min Huang. On the impact of the current downward trend of housing prices on the consumer price index [J]. Academic exchange, 2012,03:91-95.

14. Xu Chu. Research on Prediction of Consumer Price Index Based on Improved Echo State Network[J]. Modernization of Shopping Mall,2019 (15).

15. Lei Feng, Jigang Dong. Research on the Exist-

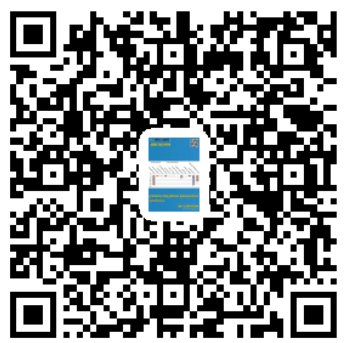
ence of Loan Interest Rate of Commercial Banks in China under Interest Rate Marketization[J]. Journal of Xi'an University of Finance and Economics, 2017(02): 45-51.

16. Ruipeng Li, Ping He, Yi Zhu. Relaxation of Loan Interest Rate Regulation and Commercial Bank Loan Efficiency[J]. , 2016, 9(01):56-86.

17. Qing Wang,Jiaming Zhu.Econometric Analysis of Factors Affecting Real Estate Price in China[J].Journal of Luoyang Teachers College,201 $7(5)$.

18. Hao Pang.Econometrics [M]. Beijing: Science Press,2014:104-105. 